\title{
In Situ Effects of Shoreline Type and Watershed Land Use on Submerged Aquatic Vegetation Habitat Quality in the Chesapeake and Mid-Atlantic Coastal Bays
}

\author{
J. Brooke Landry ${ }^{1}$ • Rebecca R. Golden ${ }^{1}$
}

Received: 16 September 2016/Revised: 17 August 2017 / Accepted: 21 August 2017 /Published online: 8 September 2017

(C) The Author(s) 2017, corrected publication 2019

\begin{abstract}
Submerged aquatic vegetation (SAV) is an ecologically and economically valuable component of coastal estuaries that acts as an early indicator of both degrading and improving water quality. This study aimed to determine if shoreline hardening, which is associated with increased population pressure and climate change, acts to degrade SAV habitat quality at the local scale. In situ comparisons of SAV beds adjacent to both natural and hardened shorelines in 24 subestuaries throughout the Chesapeake and Mid-Atlantic Coastal Bays indicated that shoreline hardening does impact adjacent SAV beds. Species diversity, evenness, and percent cover were significantly reduced in the presence of riprap revetment. A post hoc analysis also confirmed that SAV is locally affected by watershed land use associated with increased population pressure, though to a lesser degree than impacts observed from shoreline armoring. When observed over time, SAV recovery at the local level took approximately 3 to 4 years following storm impacts, and SAV adjacent to natural shorelines showed more resilience to storms than SAV adjacent to armored shorelines. The negative impacts of shoreline hardening and watershed development on SAV shown here will inform coastal zone management decisions as increasing coastal populations and sea level rise drive these practices.
\end{abstract}

Keywords Submerged aquatic vegetation $\cdot$ Riprap revetment $\cdot$ Watershed land use $\cdot$ Shoreline armoring $\cdot$ Sea level rise $\cdot$ Climate change impacts

Communicated by Marianne Holmer

J. Brooke Landry

brooke.landry@maryland.gov

1 Maryland Department of Natural Resources, 580 Taylor Avenue, C-2, Annapolis, MD 21401, USA

\section{Introduction}

Marine, estuarine, and freshwater vascular macrophytes, collectively referred to as submerged aquatic vegetation (SAV), are a globally significant, but highly threatened, coastal resource (Costanza et al. 1997; Orth et al. 2006; Fourqurean et al. 2012). For decades, these underwater grass meadows and fringing beds have been recognized for their contribution to coastal ecosystem dynamics. They provide food and habitat, as well as nursery grounds, for commercially and recreationally important finfish and shellfish (Heck et al. 2003; Beck et al. 2001; Wyda et al. 2002), and resident and migrating waterfowl depend on SAV for sustenance (Perry et al. 1981, 2007; Straub et al. 2012). SAV absorbs excess nutrients (Kenworthy et al. 1982; McGlathery et al. 2007), reducing the prevalence of algae blooms, and reduces wave and current energy (Koch 2001; Koch and Gust 1999; Gurbisz et al. 2016), thereby reducing the potential for erosion as well as promoting settlement of suspended solids and increasing water clarity. More recently, its contribution to global carbon sequestration has been highlighted (Duarte et al. 2005, 2010; Fourqurean et al. 2012), with "blue carbon" now recognized as an important tool for mitigating climate change (Laffoley and Grimsditch 2009; Crooks et al. 2011; Mcleod et al. 2011).

Approximately 17 species of SAV (Table 1), both native and non-native, are commonly found in the Chesapeake and Mid-Atlantic Coastal Bays, USA (subsequently collectively referred to as the bay unless otherwise specified) and historical records indicate that these plants once covered vast areas of the Chesapeake (Orth and Moore 1984). According to biostrategraphic records, SAV has fluctuated in abundance, spatially and temporally, throughout the bay, but generally declined following European colonization and then catastrophically decreased in the 1970s (Brush and Hilgartner 2000; Batiuk et al. 1992; Orth et al. 2010). Although SAV has since 
Table 1 Chesapeake Bay SAV species categorized by salinity tolerance. Adapted from Moore et al. (2000) and Orth et al. (2010)

\begin{tabular}{lll}
\hline Tidal fresh and oligohaline & Mesohaline & Polyhaline \\
\hline Ceratophyllum demersum & Potamogeton perfoliatus & Ruppia maritima \\
Elodea canadensis & Ruppia maritima & Zostera marina \\
Elodea nuttallii & Stukenia pectinata & \\
Heteranthera dubia & Zannichellia palustris & \\
Hydrilla verticillata & Zostera marina & \\
Myriophyllum spicatum & \\
Najas flexillis & \\
Najas guadalupensis & \\
Najas minor & \\
Potamogeton crispus & \\
Potamogeton perfoliatus & \\
Potamogeton pusillus & \\
Stukenia pectinata & \\
Vallisneria americana & \\
Zannichellia palustris & \\
\hline
\end{tabular}

recovered in some areas of the bay and its tributaries, SAV acreage is still low compared to historical levels. This trend is not unique to this ecosystem or to SAV - coastal human population pressure is negatively affecting coastal habitats globally (Lotze et al. 2006; Orth et al. 2006; Waycott et al. 2009).

The Chesapeake Bay is a 4480 mile $^{2}$ estuary with a 64,000 mile $^{2}$ watershed. This represents an approximately 14:1 land-to-water ratio, which is the largest of any coastal water body in the world (from http://www.chesapeakebay.net/ discover/bay101/facts). Li et al. (2007) found that the land-towater ratio of a given watershed and estuary is an important determinant of SAV abundance: the larger the land-to-water ratio, the larger the relative impact of the watershed on the estuary's SAV. So, while coastal population pressure is negatively affecting estuaries globally, it follows that the relative degree of potential influence from the watershed may be greater in the Chesapeake Bay than it is for other estuaries around the world.

As the land-to-water ratio determines the relative degree of the impact, the watershed land use determines the trajectory. Watershed land use has been identified as a driver of SAV abundance in the bay, with increased development and urbanization related to decreased average abundance and maintenance of forested land related to increased abundance (Li et al. 2007; Patrick et al. 2014, 2016). Although direct physical disturbances related to watershed land use impact SAV, the dominant mechanism in question here is water clarity. Water clarity is the primary limiting factor for SAV growth in the bay (Kemp et al. 2004) and watershed land use directly affects water clarity through deforestation, agricultural expansion, and urban development. All pathways contribute sediment and nutrient (phosphorus and nitrogen) pollution to the bay's waters. Suspended sediments block light, while nutrients feed phytoplankton blooms in the water column and epiphytic algae growth on SAV leaf blades (Kemp et al. 2004, 2005). Both directly reduce the incident light available for photosynthesis, and with light limitation, SAV is reduced and eventually lost if the cause of the limitation is not alleviated (Kenworthy and Fonseca 1996; Czerny and Dunton 1995; Livingston et al. 1998; Kemp et al. 2004). SAV light requirements vary by species, but due to persistent water quality degradation throughout the bay (Kemp et al. 2005), SAV is generally limited to the nearshore shallow areas, less than $2 \mathrm{~m}$ deep. This places SAV at the land-water interface and brings into question the additional impacts of shoreline armoring on SAV.

Shoreline armoring is the placement of riprap revetments, seawalls, bulkheads, groins, jetties, and breakwaters along a shoreline in order to stabilize sediments and prevent erosion and property loss (Living Shoreline Steering Committee 2006; Charlier et al. 2005; Griggs 2005; Stancheva et al. 2011). It is estimated that $14 \%$ of the US coastline is armored (Hawaii and Alaska were not included in the analysis) and that $64 \%$ of sheltered shorelines, such as estuaries, lagoons, and tidal rivers, are armored (Gittman et al. 2015). Although the shoreline protective value of nearshore SAV meadows has long been recognized as an important ecosystem service, this trend toward engineered defenses and shoreline hardening is pervasive in the Chesapeake Bay as well and anticipated to accelerate in response to climate change and sea level rise.

Regardless of the rapid proliferation of coastal armoring structures, the effects of shoreline armoring on SAV habitats and other coastal ecosystem functions and communities have only recently been addressed (NRC 2007; Patrick et al. 2014, 2016; Scyphers et al. 2015; Blake et al. 2014; Morley et al. 2012; O'Connor et al. 2010; Bulleri and Chapman 2010; Gittman et al. 2015; Kittinger and Ayers 2010; Stancheva et al. 2011). Through innovative techniques in spatialstatistical modeling, Patrick et al. $(2014,2016)$ were able to elucidate to what degree varying shoreline characteristics and watershed land uses have on SAV in the Chesapeake and MidAtlantic Coastal Bays. Of particular interest, Patrick et al. (2014) compared riprap prevalence (percent of shoreline riprapped within a defined subestuary) and watershed land use (determined by percent of subwatershed forested, in cropland, or developed) with SAV abundance. The results of this study demonstrated that riprap has a significantly negative impact on SAV acreage and that subestuaries with more or less than $5.4 \%$ riprapped shoreline follow different trajectories in SAV abundance over time. Subestuaries with less than $5.4 \%$ riprapped shoreline showed a steady and significant increase over time, whereas subestuaries with less than $5.4 \%$ riprapped shoreline showed no significant trend. Likewise, in a follow-up analysis, Patrick et al. (2016) used individual shoreline segments and adjacent SAV beds as their study units, rather than subestuary average values. This allowed for the separation of watershed land use and shoreline effects, which were confounded in the 
original study. Their results suggest that shoreline armoring does in fact directly affect adjacent SAV habitat.

The intent of this study was to complement and supplement the larger spatial-statistical analyses undertaken by Patrick et al. (2014, 2016) that utilized maps of SAV distribution interpreted from aerial imagery, with local in situ assessments of SAV habitat quality and quantity throughout the Chesapeake and MidAtlantic Coastal Bays. While compelling, spatial modeling cannot replace field studies and in situ assessments of SAV habitat characteristics, such as percent cover, species diversity, and patchiness - all parameters that tell more about the quality and potential resilience of the SAV habitat rather than the quantity.

It was our goal, therefore, to determine what SAV habitat characteristics were affected in the presence of shoreline armoring, specifically riprap revetment. To do so, we surveyed SAV beds in 24 subestuaries that represent a range of salinity regimes and watershed land use categories throughout the Chesapeake and Mid-Atlantic Coastal Bays (Fig. 1, Table 2). In each subestuary, we compared SAV beds adjacent to natural shorelines with SAV beds adjacent to shorelines armored with riprap to determine what effect, if any, shoreline modification has on SAV habitats immediately offshore. Of these 24, 6 were set as long-term monitoring sites and surveyed every summer for 6 years during peak biomass. By establishing long-term sites, it was our intent to discern if SAV abundance and habitat quality adjacent to natural shorelines showed a different trajectory than SAV abundance and habitat quality adjacent to shorelines with riprap, particularly with regard to recovery following a disturbance. Additionally, to determine if the effects of watershed land use were discernible at the local scale, we conducted a post hoc analysis to compare SAV cover and bed characteristics in watersheds categorized as having forested, agricultural, developed, or mixed-use land cover.

This study tested the hypotheses that riprap revetment negatively impacts SAV habitat characteristics, as well as reduces SAV recovery from disturbance. We also hypothesized that SAV habitat is more negatively impacted in estuaries of developed watersheds compared to mixed-other, agricultural, and forested watersheds. The direct response of SAV was quantified by measuring total and individual SAV species percent covers, bed size, start of bed distance from shore, water depth at start and end of bed, and presence of epiphytes on SAV leaf blades.

\section{Methods}

\section{GIS Site Selection Methodology and Data Sources}

Twenty-four subestuaries and their corresponding watersheds, a small subset of those previously delineated and described by Li et al. (2007) and Patrick et al. (2014), were selected to represent a range of salinity regimes (as a proxy for SAV community type) and watershed land uses (Fig. 1, Table 2). Patrick et al. (2014) used the following watershed categories in their analyses: forested ( $\geq 60$ forest and forested wetland), developed ( $\geq 50 \%$ developed land), agricultural ( $\geq 40 \%$ cropland), mixed-developed (15-50\% developed land), mixedagricultural (20-40\% cropland), and mixed-other (watersheds that did not fit into any of the other categories). Classification was based on dominant land cover data summarized from the National Land Cover Dataset 2001 (Homer et al. 2007). To increase the sample size for analytical purposes, we combined mixed-developed with developed, and mixed-agricultural with agricultural, yielding four land use categories for this study: developed ( $\geq 15 \%$ developed), agricultural $(\geq 20 \%$ cropland), mixed other, and forested ( $\geq 60 \%$ forest and forested wetland).

For selection, subestuaries also had to adhere to the following criteria: (1) must have at least $5 \%$ of the shallow water $(<$ $2 \mathrm{~m}$ ) area occupied by SAV at least 1 year from 2004 to 2008 and some SAV present in 2009, (2) must have at least $5 \%$ of their shoreline armored with riprap, and (3) must have sufficient shoreline and SAV treatment combinations as determined by the experimental design (natural shoreline + offshore SAV bed, armored shoreline + offshore SAV bed) during the sampling year. SAV distribution was determined using publicly available data from the Virginia Institute of Marine Science (VIMS) SAV Aerial Survey Program (http://web. vims.edu/bio/sav/). Shoreline data was obtained from publicly available shoreline inventories conducted by VIMS Center for Coastal Resources Management (http://www.vims. edu/ccrml).

When determining sites to survey within each subestuary, only treatment combinations located within $1 \mathrm{~km}$ of one another, along the same shoreline, and with similar fetch were selected.

\section{Field Sampling Methodology}

At each selected site, paired transects were haphazardly placed at least $10 \mathrm{~m}$ apart to maintain independence and run perpendicular to the shoreline for each treatment type. To mark the beginning of each transect, a weighted dive buoy was placed at the shoreward edge of the SAV bed. From the shoreward edge of the bed, a survey tape was run to the offshore edge of the SAV bed and set using a second weighted dive buoy. Transect length was dependent on the distance the SAV bed extended from the shoreward edge of bed; however, if the SAV bed extended farther than $200 \mathrm{~m}$ from shore, transects were terminated at $200 \mathrm{~m}$. Termination at $200 \mathrm{~m}$ was based on an assumption that shoreline influence was minimal beyond $200 \mathrm{~m}$, as well as to ensure diver safety as beds often extended up to navigation channels. The beginning and end of each transect were georeferenced using handheld Garmin GPS units. 


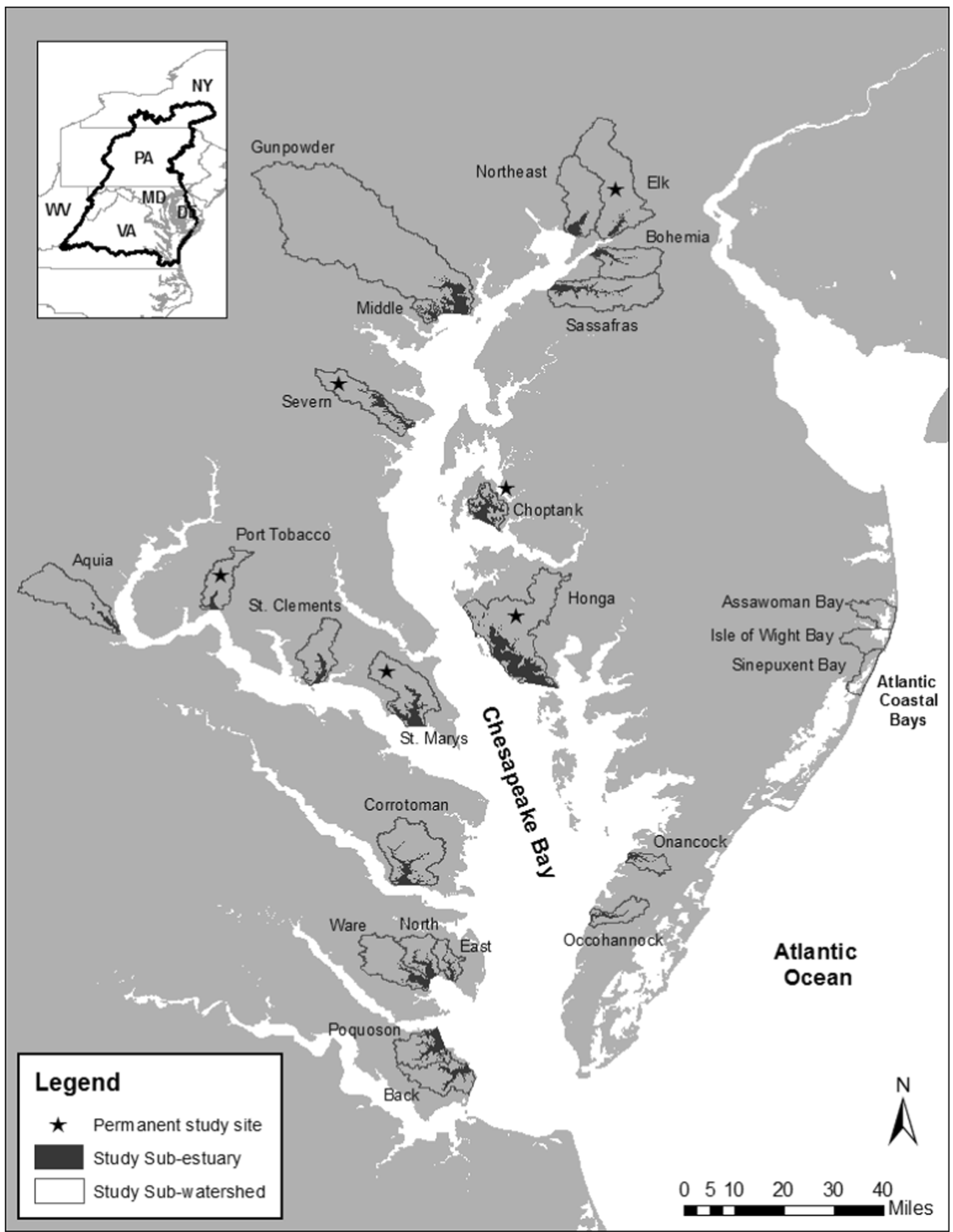

Fig. 1 Location of 24 study areas in Chesapeake and Atlantic Coastal Bays. Subwatersheds are outlined and subestuaries are shaded. Six long-term monitoring sites are starred 
Eleven $0.25 \mathrm{~m}^{2}$ quadrats were sampled along the length of each transect at even intervals, including the start and end of the bed, for a total $n=11$ quadrats for each transect and $n=22$ quadrats for each treatment type at each site. At each quadrat, the following visual estimates and measurements were taken: total SAV percent cover, percent cover of each individual species, epiphyte presence on SAV leaf blades, and water depth. The distance from the shoreward edge of the SAV bed to the mean low water line was also measured.

All subestuaries were sampled once between 2010 and 2012 during peak biomass of the dominant SAV community (May-June for polyhaline, June-July-August for mesohaline, and August-September for oligohaline and tidal fresh). Six of the 24 subestuaries were selected as long-term monitoring sites and surveyed every summer for 6 years (2010-2015). These sites were selected based on travel distance and accessibility of the site from shore. Because the authors planned to designate these as long-term sentinel sites to monitor beyond the scope of this project, they also needed to be within the state of Maryland and represent areas that were not already monitored by other institutions. These requirements resulted in the selection of four mesohaline sites and two oligohaline sites including the Elk, Port Tobacco, Severn, Honga, Choptank, and St. Mary's Rivers (Fig. 1, Table 2). Salinity regime and land use were not considered in long-term monitoring site selection.

\section{Analytical Methodology}

The effects of shoreline type (natural, riprap) and subestuary land use (forested, agricultural, developed, or mixed other) on adjacent SAV community and habitat response variables (SAV $\%$ cover and frequency of occurrence, species richness, Shannon diversity and Pielou's evenness indices, bed width, water depth at start and end of bed, slope, start of bed distance to shore, and epiphyte occurrence) were assessed using separate mixed model analyses (PROC MIXED) in SAS Enterprise Guide. Shoreline type and subestuary land use were treated as fixed factors, with Subestuary (nested in Land use), Transect (nested in Shoreline Type), and Quadrat (nested in Transect) treated as random effects. If significant interactions were observed, post hoc comparisons were made using the least squares method (with Tukey Kramer adjustment). Data were tested for homogeneity of variances (Levene's test).
Table 2 Chesapeake and Coastal Bay study subestuaries

\begin{tabular}{|c|c|c|c|c|c|}
\hline Segment & Subestuary & Salinity & Land use & $\begin{array}{l}\text { Watershed to } \\
\text { estuary ratio }\end{array}$ & $\begin{array}{l}\text { Percent } \\
\text { riprap }\end{array}$ \\
\hline NOR01 & Northeast & $\mathrm{TF}$ & Mixed Other & 12.63 & 18.64 \\
\hline ELK01 & Elk $^{\mathrm{a}}$ & $\mathrm{O}$ & Mixed Other & 37.91 & 6.08 \\
\hline ELK02 & Bohemia & $\mathrm{O}$ & Agricultural & 11.59 & 5.28 \\
\hline SAS01 & Sassafras & $\mathrm{O}$ & Forested & 8.32 & 4.35 \\
\hline GUN01 & Gunpowder & $\mathrm{O}$ & Mixed Other & 24.83 & 6.02 \\
\hline MID01 & Middle & $\mathrm{O}$ & Developed & 3.45 & 10.87 \\
\hline $\mathrm{POC} 02$ & Port Tobacco ${ }^{a}$ & $\mathrm{O}$ & Mixed Other & 14.68 & 2.78 \\
\hline POT10 & Aquia & $\mathrm{O}$ & Forested & 24.06 & 4.39 \\
\hline SEV01 & Severn $^{\mathrm{a}}$ & M & Developed & 6.74 & 8.13 \\
\hline $\mathrm{CHO} 2$ & Choptank $^{\mathrm{a}}$ & M & Agricultural & 2.32 & 35.80 \\
\hline HNG01 & Honga $^{a}$ & M & Mixed Other & 2.47 & 5.66 \\
\hline РОТ02 & St. Mary's ${ }^{a}$ & M & Mixed Other & 5.97 & 8.49 \\
\hline РОT04 & St. Clements & M & Mixed Other & 9.37 & 4.56 \\
\hline RPP01 & Corrotoman & $\mathrm{P}$ & Forested & 8.36 & 16.71 \\
\hline MOB01 & East (Mobjack Bay) & $\mathrm{P}$ & Forested & 6.79 & 6.95 \\
\hline MOB02 & North (Mobjack Bay) & $\mathrm{P}$ & Forested & 5.66 & 5.32 \\
\hline MOB03 & Ware (Mobjack Bay) & $\mathrm{P}$ & Forested & 9.18 & 4.40 \\
\hline CB602 & Poquoson & $\mathrm{P}$ & Developed & 3.81 & 9.91 \\
\hline CB603 & Back & $P$ & Developed & 6.65 & 0.95 \\
\hline CB701 & Onancock & $\mathrm{P}$ & Agricultural & 6.33 & 3.24 \\
\hline CB705 & Occohannock & $\mathrm{P}$ & Agricultural & 9.03 & 2.78 \\
\hline CB04 & Assawoman & $\mathrm{P}$ & Agricultural & 2.74 & 4.28 \\
\hline CB06 & Isle of Wight & $\mathrm{P}$ & Developed & 3.26 & 9.55 \\
\hline CB08 & Sinepuxent & $\mathrm{P}$ & Mixed Other & 2.12 & 9.68 \\
\hline
\end{tabular}

TF tidal fresh, $O$ oligohaline, $M$ mesohaline, $P$ polyhaline

${ }^{\text {a }}$ Indicates long-term monitoring site 
Long-term monitoring sites were tested for the impacts of Shoreline Type over time on SAV community and habitat variables (SAV \% cover and frequency of occurrence, species richness, Shannon diversity and Pielou's evenness indices, bed width, water depth at start and end of bed, slope, start of bed distance to shore, and epiphyte occurrence) using a mixed model analysis (PROC MIXED) in SAS Enterprise Guide. Shoreline Type and Year were treated as fixed factors; Subestuary, Transect (nested in Shoreline Type), and Quadrat (nested in Transect) were random factors. If significant interactions were observed, post hoc comparisons were made using the least squares method (with Tukey Kramer adjustment).

Species richness was defined as the total number of species observed at each treatment. The Shannon Weiner Index and Pielou's evenness, which account for both species richness and relative abundance of each species to determine how well a species is represented within a community, were calculated from the total SAV percent cover and individual species percent cover for each transect. Frequency of occurrence (number of quadrats where observed/total number of quadrats) for each species or genera at each site was also calculated.

SAV bed widths (meters) were determined from transect lengths, which ranged from 15 to $200 \mathrm{~m}$ depending on the site, and the slope $(\mathrm{cm} / \mathrm{m})$ at each transect was calculated as the maximum water depth minus the minimum water depth/ total transect length.

\section{Results}

The 24 subestuaries selected for this study represented all four salinity regimes ( 1 tidal fresh $(<0.5 \mathrm{ppt}), 7$ oligohaline $(0.5$ $5 \mathrm{ppt}$ ), 5 mesohaline (5-18 ppt), and 11 polyhaline (> $18 \mathrm{ppt})$ ), as well as four land use categories: forested (6), agricultural
(5), developed (5), and mixed other (8) (Table 2). Subestuaries also ranged from being minimally armored with riprap $(<1 \%)$ to heavily armored with riprap (35.8\%) and represented a wide range of watershed to subestuary size ratios (2.12 to $37.9 \%$ ) (Table 2).

\section{Effects of Shoreline Armoring}

Results indicate that several SAV bed characteristics related to habitat quality and resilience were significantly higher in SAV beds adjacent to natural shorelines compared to armored shorelines. Mean SAV percent cover in beds adjacent to natural shorelines was 38\% compared to 33\% in SAV beds adjacent to armored shorelines. This difference was significant at $p=0.003$. Diversity and evenness were also significantly higher ( $p=0.001$ and 0.003 , respectively) in SAV beds adjacent to natural shorelines compared to SAV beds adjacent to armored shorelines (Table 3). Finally, SAV beds adjacent to riprapped shoreline had significantly deeper water depths $(p=0.047)$ at the shoreward edge of bed compared to SAV beds adjacent to natural shorelines (Table 3 ).

Other response variables measured or calculated include SAV frequency of occurrence, richness, bed width, water depth at the end of bed, slope, start of bed distance to shore, and epiphyte presence. No statistically significant differences were observed for these parameters between the two shoreline types, although average SAV bed widths were 1.3 times greater adjacent to natural shorelines (Table 3).

\section{Effects of Watershed Land use}

When natural and armored shoreline data were grouped and analyzed by land use type rather than shoreline type, we found that watersheds categorized as developed supported less SAV
Table 3 Comparison of SAV habitat parameters between natural (NAT) and riprap (RR) shorelines

\begin{tabular}{|c|c|c|c|c|c|}
\hline Variable & $\begin{array}{l}\text { Shoreline } \\
\text { trend }\end{array}$ & $\begin{array}{l}\text { Mean } \pm \text { SE } \\
\text { NAT }\end{array}$ & $\begin{array}{l}\text { Mean } \pm \mathrm{SE} \\
\mathrm{RR}\end{array}$ & $F$ & $p$ \\
\hline SAV $\%$ cover & $\mathrm{NAT}>\mathrm{RR}$ & $38.2 \pm 5.07$ & $33.4 \pm 5.07$ & 8.85 & $0.003 * *$ \\
\hline SAV frequency & $\mathrm{NAT}>\mathrm{RR}$ & $0.945 \pm 0.023$ & $0.908 \pm 0.023$ & 2.51 & 0.120 \\
\hline Bed width (m) & $\mathrm{NAT}>\mathrm{RR}$ & $122.13 \pm 12.02$ & $92.09 \pm 12.04$ & 18.13 & $0.051 *$ \\
\hline Richness & $\mathrm{NAT}>\mathrm{RR}$ & $2.1 \pm 0.3$ & $1.9 \pm 0.3$ & 1.53 & 0.228 \\
\hline Shannon diversity index & $\mathrm{NAT}>\mathrm{RR}$ & $0.1114 \pm 0.0233$ & $0.0741 \pm 0.0234$ & 10.31 & $0.001 * * *$ \\
\hline Pielou's evenness index & $\mathrm{NAT}>\mathrm{RR}$ & $0.0498 \pm 0.0099$ & $0.0342 \pm 0.0099$ & 8.84 & $0.003 * *$ \\
\hline Depth at start of bed $(\mathrm{cm})$ & $\mathrm{NAT}<\mathrm{RR}$ & $48.35 \pm 4.67$ & $63.85 \pm 4.68$ & 19.97 & $0.047 *$ \\
\hline Depth at end of bed $(\mathrm{cm})$ & $\mathrm{NAT}<\mathrm{RR}$ & $113.78 \pm 7.24$ & $116.97 \pm 7.27$ & 0.38 & 0.602 \\
\hline Slope $(\mathrm{cm} / \mathrm{m})$ & $\mathrm{NAT}<\mathrm{RR}$ & $0.72 \pm 0.11$ & $0.87 \pm 0.11$ & 2.18 & 0.147 \\
\hline $\begin{array}{l}\text { Start of bed distance to } \\
\text { shore (m) }\end{array}$ & $\mathrm{NAT}<\mathrm{RR}$ & $4.88 \pm 0.92$ & $5.48 \pm 0.92$ & 0.77 & 0.385 \\
\hline Epiphyte occurrence & $\mathrm{NAT}<\mathrm{RR}$ & $0.5046 \pm 0.0753$ & $0.5688 \pm 0.0758$ & 0.92 & 0.336 \\
\hline
\end{tabular}

*Indicates a significant statistical difference with $p<0.05$; **indicates a significant statistical difference with $p<$ $0.01 ; * * *$ indicates a significant statistical difference with $\mathrm{p}<0.001$ 
in their corresponding subestuaries than subestuaries in forested watersheds (Table 4). Total SAV percent cover was significantly higher $(p=0.041)$ in forested watersheds compared to those categorized as developed, but not significantly different from that in agricultural or mixed other (Table 4). Mean SAV percent cover ranged from $55 \%$ in forested subestuaries to $18 \%$ in developed watersheds.

Water column depths at the offshore edge of SAV beds were found to be significantly deeper $(p=0.044)$ in forested watershed subestuaries compared to those in subestuaries of mixed-other watersheds, but not statistically different from those in developed or agricultural watersheds (Table 4).

Other SAV bed characteristics measured or calculated were not found to be statistically different based on watershed land use. These parameters include SAV frequency of occurrence, species richness, diversity and evenness, bed width, water depth at the shoreward edge of bed, start of bed distance to shore, slope, and epiphyte prevalence (Table 4).

\section{Effects of Shoreline Armoring and Annual Variability at Long-Term Monitoring Sites}

Six sites were surveyed each year from 2010 to 2015 during their respective periods of peak SAV biomass (Table 2), with the exception of Port Tobacco and St. Mary's Rivers, which were not surveyed in 2015. Two large-scale storms impacted the Chesapeake Bay region in late August (Hurricane Irene) and early September (Tropical Storm Lee), 2011, which allowed for the assessment of SAV recovery at these sites following a disturbance. Analyses over the 6-year monitoring period suggest that shoreline modification as well as annual variability significantly impacted SAV habitat quality, as displayed in Fig. 2 and Table 5.

SAV beds adjacent to natural shorelines had significantly higher $(p<0.0001)$ SAV percent cover, SAV species richness, and Shannon diversity and Pielou's evenness, relative to armored shorelines regardless of year. Likewise, annual variability accounted for significant differences in SAV percent cover and frequency of occurrence, species richness, Shannon diversity and Pielou's evenness, epiphyte presence, SAV bed width, and depth at end of bed. There were significant interactions between shoreline type and year for total SAV percent cover and Pielou's evenness (Fig. 2a and b, Table 5).

SAV frequency of occurrence was higher $(p=0.0002)$ in 2015, followed by 2010 and 2011, compared to that in previous years (Fig. 2c). Species richness, diversity, and evenness were the highest $(p<0.0001)$ in 2010 and 2015 compared to those in other years (Fig. 2d, e, and b, Table 5). Epiphyte frequency of occurrence was highest ( $p=0.0027$ ) in 2012 (Fig. 2f). SAV bed width was significantly lower $(p=0.0162)$ in 2014 compared to that in all other years (except 2010), while water depth at the end of SAV bed was deepest in 2015 (Fig. $2 \mathrm{~g}$ and $\mathrm{h}$ ).

While there were no significant differences in percent cover between shoreline types in the years prior to Hurricane Irene and Tropical Storm Lee (2010 and 2011), SAV percent cover was significantly higher at natural shorelines in the 2 years following the storms (2012 and 2013). In 2014 and 2015, percent cover was no longer significantly different between shoreline types (Fig. 2a).

Similarly, evenness, or how equally species are distributed, was significantly higher at natural shorelines in 2011 (prior to the storms). In the years following the storms (2012-2014), evenness was comparable between shoreline types. In 2015, natural shorelines had significantly higher evenness than armored shorelines (Fig. 2b).

\section{Discussion}

Population growth and human-dominated watershed land use are drivers of degradation in coastal habitats around the world (Lotze et al. 2006; Orth et al. 2006; Bulleri and Chapman 2010; Gittman et al. 2015). With approximately 18 million people currently residing in the Chesapeake Bay watershed
Table 4 Comparison of SAV habitat parameters among four land use categories: forest (For), mixed other (Mix), agriculture (Ag), and developed (Dev)

\begin{tabular}{llll}
\hline Variable & Land use trend & F & $p$ \\
\hline SAV \% cover & For $>$ Mix $>$ Ag $>$ Dev & 3.11 & $0.032^{*}$ \\
SAV frequency & For $>$ Mix $>$ Ag $>$ Dev & 1.33 & 0.2916 \\
Bed width (m) & For $>$ Mix $>$ Ag $>$ Dev & 2.34 & 0.0850 \\
Richness & For $>$ Mix $>$ Ag $>$ Dev & 0.44 & 0.7274 \\
Shannon diversity index & For $>$ Dev $>$ Mix $>$ Ag & 0.22 & 0.8833 \\
Pielou's evenness index & Dev $>$ For $>$ Mix $>$ Ag & 0.22 & 0.8835 \\
Depth at start of bed (cm) & Dev $>$ Mix $>$ For $>$ Ag & 0.49 & 0.6960 \\
Depth at end of bed (cm) & For $>$ Dev $>$ Ag $>$ Mix & 2.86 & $0.0437^{*}$ \\
Slope $(\mathrm{cm} / \mathrm{m})$ & Ag $~$ & 2.92 & Dev $>$ Mix \\
Start of bed distance to shore (m) & Dev $>$ Mix $>$ For $>$ Ag & 1.12 & 0.0580 \\
Epiphyte occurrence & Mix $>$ For $>$ Ag $>$ Dev & 0.65 & 0.3616 \\
\hline
\end{tabular}

*Indicates a significant statistical difference with $p<0.05$ 


$$
\text { 高。 }
$$

a
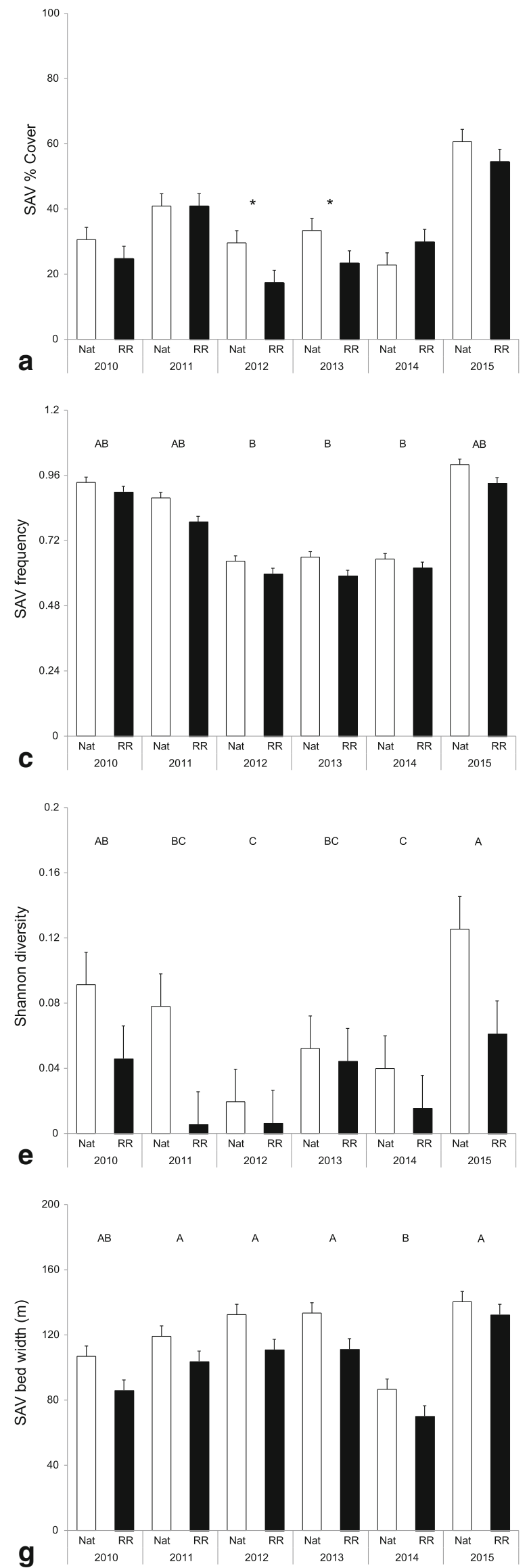
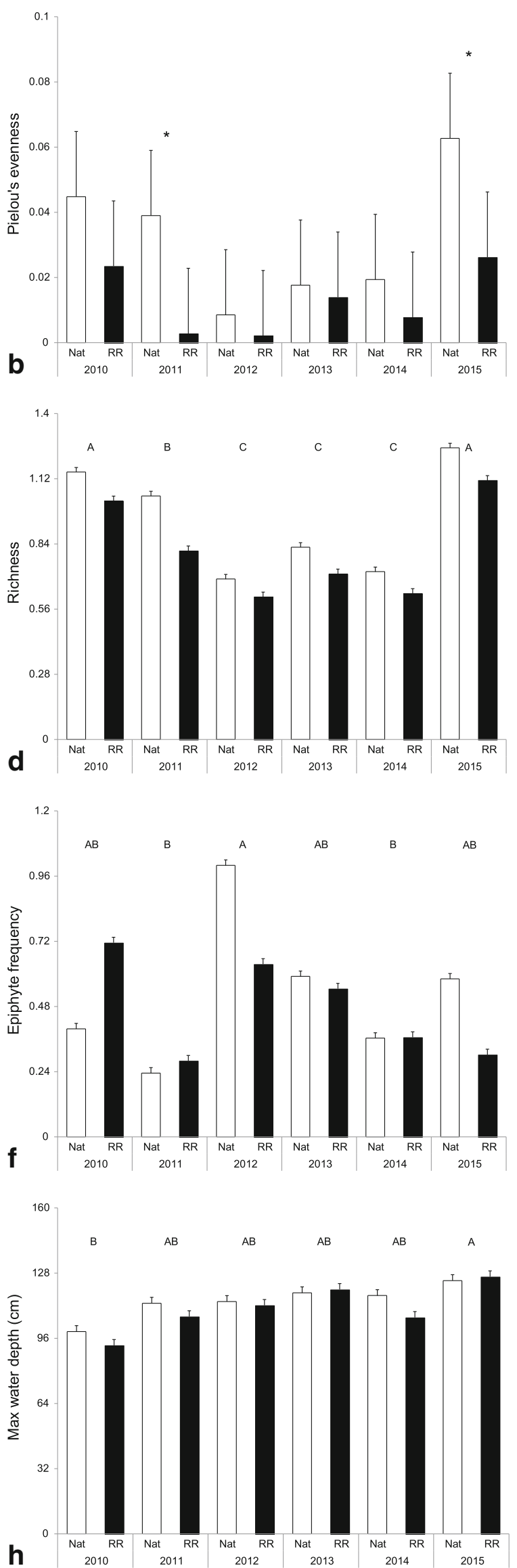
Fig. 2 Mean SAV percent cover (a), Pielou's evenness (b), SAV frequency of occurrence (c), richness (d), Shannon diversity index (e), epiphyte frequency (f), SAV bed width (g), and water depth at end of bed (h) by shoreline type (NAT = natural, RR = riprap) and sampling year (2010-2015). Error bars show standard error. Asterisks denote significant $(p<0.05)$ interactions between shoreline type and sampling year. Letters denote significant $(p<0.01)$ differences between sampling years

and the population of the watershed projected to rise to 20 million by 2030 (www.chesapeakebay.net), Chesapeake Bay is no exception (Kemp et al. 2005; Orth et al. 2006). Fortunately, the Chesapeake is also one of the most studied estuaries in the world, and with an understanding of the impacts of our anthropogenic influences comes the capacity to alleviate or even reverse the effects of those stressors. This study aimed to provide unique and detailed information regarding local-scale impacts to SAV habitat quality to the existing knowledge base that can be used to guide responsible and sustainable management decisions and long-term planning at the local or watershed level.

\section{Effects of Shoreline Armoring}

With this in situ assessment of SAV habitats throughout the Chesapeake and Mid-Atlantic Coastal Bays, we have demonstrated that riprap revetments negatively affect adjacent beds of SAV. These results compliment those of Patrick et al. (2014, 2016), but provide additional information regarding the response of SAV bed characteristics associated with habitat quality and resilience. Habitat quality and resilience refer to a system's ecological functionality and ability to withstand or recover from disturbance (Gurbisz et al. 2016). Species diversity, for example, is a key component of both habitat quality and resilience. A greater number of species and individuals of a species dispersed throughout a population (diversity) create a habitat that is not only beneficial to the organisms that find food and refuge within, but are also important to the physical stability of the habitat (Duffy 2006). While multiple levels of trophic interactions are supported in habitats of higher complexity, those individual species respond differently and more or less effectively to physical stressors as well (Orth et al. 2010). Frequency of occurrence, likewise, is a measure of patchiness in an SAV bed. Patchiness - when small or large areas in an SAV bed are free of plants and have exposed sediment — can make a bed more susceptible to sheer stress associated with increased flow during storm events. Large, dense SAV beds, on the other hand, have been shown to be more resilient to this type of disturbance (Gurbisz et al. 2016).

In this study, SAV beds adjacent to natural shorelines had significantly higher percent cover, species diversity, and species evenness (Table 3), indicating that SAV beds adjacent to natural shorelines maintain higher habitat quality and resilience to disturbance than those adjacent to riprap. This finding provides a possible explanation for the Patrick et al. (2014) assertion that watersheds with more or less than $5.4 \%$ riprapped shoreline follow different trajectories in SAV abundance over time, in which subestuaries with less than $5.4 \%$ riprapped shoreline showed a steady and significant increase over time, and subestuaries with less than $5.4 \%$ riprapped shoreline showed no significant trend. If riprap acts to degrade the habitat quality and resilience of adjacent SAV beds as this study shows, by reducing cover, diversity, and evenness, those beds will not withstand disturbance or recover from disturbance over time as efficiently as SAV beds adjacent to natural shorelines, gradually reducing a subestuary's overall SAV abundance.

Surprisingly, we did not observe a statistical difference in frequency of occurrence, or patchiness, between shoreline types, which would have been expected based on significant
Table 5 ANOVA results for the effects of shoreline type, year, and shoreline $\times$ year interactions on SAV habitat characteristics

\begin{tabular}{|c|c|c|c|c|c|c|}
\hline \multirow[t]{2}{*}{ Variable } & \multicolumn{2}{|c|}{ Shoreline } & \multicolumn{2}{|c|}{ Annual } & \multicolumn{2}{|c|}{ Shoreline $\times$ annua } \\
\hline & $F$ & $p$ & $F$ & $p$ & $F$ & $p$ \\
\hline SAV $\%$ cover & 6.97 & $0.0084 *$ & 37.25 & $<0.0001 * * *$ & 3.67 & $0.0026^{* *}$ \\
\hline SAV frequency & 1.03 & 0.4175 & 5.28 & $0.0002 * *$ & 0.03 & 0.9996 \\
\hline Bed width (m) & 6.72 & 0.1221 & 4.95 & $0.0004 * *$ & 0.09 & 0.9933 \\
\hline Richness & 17.81 & $<0.0001 * * *$ & 37.83 & $<0.0001 * * *$ & 0.83 & 0.4300 \\
\hline Shannon diversity index & 20.74 & $<0.0001^{* * *}$ & 7.95 & $<0.0001 * * *$ & 1.73 & 0.1238 \\
\hline Pielou's evenness index & 28.17 & $<0.0001^{* * *}$ & 9.85 & $<0.0001 * * *$ & 2.57 & $0.0253 *$ \\
\hline Depth at start of bed $(\mathrm{cm})$ & 1.65 & 0.3273 & 2.11 & 0.0707 & 0.79 & 0.5617 \\
\hline Depth at end of bed $(\mathrm{cm})$ & 0.90 & 0.4419 & 2.42 & $0.041^{*}$ & 0.14 & 0.9811 \\
\hline Slope $(\mathrm{cm} / \mathrm{m})$ & 2.49 & 0.2551 & 0.67 & 0.6506 & 0.61 & 0.6915 \\
\hline Start of bed distance to shore $(\mathrm{m})$ & 3.35 & 0.2088 & 1.45 & 0.2131 & 1.03 & 0.4084 \\
\hline Epiphyte occurrence & 0.25 & 0.6662 & 8.72 & $<0.0001 * * *$ & 1.63 & 0.1672 \\
\hline
\end{tabular}

*Indicates a significant statistical difference with $p<0.05$; **indicates a significant statistical difference with $p<$ $0.01 ; * *$ indicates a significant statistical difference with $\mathrm{p}<0.001$ 
reductions in cover and diversity at riprapped shorelines. This may be attributed to frequency being a simple measure of presence or absence of SAV in each quadrat-SAV cover could be minimal but would still be considered present and contribute to the calculated frequency of SAV at that transect. It is also worth considering that SAV presence was a criterion for assessment in this study, and as frequency is a measure of presence, our inherent site selection bias may have precluded our ability to measure differences in this parameter between treatment types.

\section{Effects of Watershed Land use}

Our post hoc analysis of watershed land use showed that human-dominated land use negatively influenced SAV habitat at the site-specific scale regardless of shoreline type for some bed characteristics. We found that watersheds categorized as forested supported more SAV, measured as percent cover, in their subestuaries than developed watershed subestuaries (Table 4), which is consistent with the results from Patrick et al. $(2014,2016)$. We also found significantly greater depth at the offshore end of beds in forested watershed subestuaries. Increased percent cover and depth suggest better water clarity in forested watersheds - with clearer water, SAV are able to grow to deeper depths.

SAV percent cover and water depth at the end of bed were the only parameters significantly higher in forested watersheds, which suggests that impacts from shoreline alteration may be more detrimental at the local scale than general watershed degradation. While this may certainly be the case, it was expected that other significant differences would be detected as well. We suggest two possible explanations here for why they were not. First, in order to assess watershed land use impacts, we grouped together data from both shoreline treatments (natural and riprap), which could have had a "canceling out" effect from both treatment types. The second, and more likely, possibility is that when assigning land use categories to our selected watersheds, it was necessary to group categories together in order to have large enough sample sizes for the post hoc analysis. Specifically, watersheds categorized as mixed developed by Patrick et al. (2014) were grouped with those categorized as developed, and mixed-agricultural watersheds were grouped with agricultural watersheds. This means that our developed category was a watershed with more than $15 \%$ developed land (compared to $>50 \%$ ) and our agricultural category was a watershed with more than $20 \%$ cropland (compared to $>40 \%$ ). Relative to our forested watersheds, which required more than $60 \%$ forested land (there were no mixedforested categories), the negative impacts from these more broadly categorized agricultural and developed watersheds would be more difficult to detect than the benefits of a watershed with more than $60 \%$ forested land cover. This also explains why our results were not evident in favor of forested watersheds when compared to analyses conducted by Patrick et al. (2014). Unfortunately, our sample sizes would have been too small to run analyses without these broader groupings. Obtaining in situ data from an increased number of subestuaries would greatly increase our understanding of watershed land use at the local scale.

\section{Effects of Shoreline Armoring over Time and on SAV Recovery}

When tracked over time, shoreline armoring as well as annual variability affected SAV habitat characteristics. Similar to the larger shoreline analysis, natural shorelines had higher SAV percent cover, species richness, diversity, and evenness relative to armored shorelines regardless of year, but annual variability also accounted for differences in SAV percent cover, frequency, diversity, and SAV bed width. Significant interactions were found between shoreline type and year for total percent cover and evenness (Fig. 2, Table 5).

Two storms allowed us to track recovery at our long-term monitoring sites. Hurricane Irene and Tropical Storm Lee swept through the Chesapeake Bay region in late August and early September, 2011 and reduced SAV in areas of the bay in the following year (http://web.vims.edu/bio/sav/). Eastern shore tributaries were particularly affected by Hurricane Irene while the upper bay and tributaries were more heavily affected by Tropical Storm Lee (https://md. water.usgs.gov/waterdata/chesinflow/). SAV was impacted by turbidity blooms and siltation, as well as scour from increased water flow associated with the back-to-back weather events. Species richness and Shannon diversity were significantly higher in 2015 and 2010 at our long-term sites, compared to those in other years. Similarly, SAV frequency of occurrence was observed to be significantly highest in 2015 , 2010 , and 2011, indicating a reduction in diversity and an increase in patchiness following the storms (Fig. 2, Table 5).

While there were no significant differences in total SAV percent cover between natural shorelines or hardened shorelines in the years preceding the storms (2010 and 2011), percent cover was significantly higher at natural sites for 2 years after the storms (2012 and 2103). In 2014 and 2015, there were no longer differences in percent cover between the two shoreline types. This suggests that SAV adjacent to natural shorelines was not as affected by the storms, or that SAV recovered more quickly at natural sites. Site evenness was also significantly greater at natural shorelines in 2011 and 2015 (Fig. 2, Table 5), suggesting SAV species composition was more equally distributed these years. Together, these results suggest that SAV at the local level took approximately 3 to 4 years to recover to pre-storm conditions, and that the presence of riprap inhibited SAV recovery after a disturbance compared to natural shorelines. 
The site-specific recovery in SAV observed in this study coincided with and may have been accelerated by bay-wide increases in water quality and clarity (http://www.chesapeakebay. net/data/downloads/cbp_water_quality_database_1984_ present) and was not isolated to our study sites. 2015 was a record year for SAV throughout the Chesapeake Bay (http:// web.vims.edu/bio/sav/sav15/index.html), suggesting that the bay's SAV are responding to the U.S. Environmental Protection Agency's Chesapeake Bay Total Maximum Daily Load (TMDL, https://www.epa.gov/chesapeake-bay-tmdl), which is a comprehensive "pollution diet" to restore water quality and clarity in the Chesapeake Bay and the region's streams, creeks, and rivers. The impact of recent water quality improvements may have been stronger than the localized impacts of shoreline armoring and watershed land use.

\section{Contemplation of Causal Mechanisms}

Together, our results suggest that riprap, and to a lesser degree watershed land use, acts to degrade the quality and resilience of SAV habitat at the local scale by decreasing SAV percent cover, diversity, and evenness. This study also suggests that SAV recovery from storm damage may be temporally inhibited by shoreline armoring. While it was not our intent to determine causal mechanisms, the effects of shoreline armoring on the physical processes of nearshore coastal habitats have been examined by others. Goforth and Carman (2005) observed that sediment stability decreased adjacent to developed shorelines, while Heerhartz et al. (2016) observed a decrease in sediment exchange as a result of shoreline armoring. Site observations made during the course of this study suggested increased nearshore scour at sites with riprap (increased water depth at start of bed, Table 3), which is caused by increased wave reflection by riprap (Kraus and Pilkey 1988). Increased wave energy and scour would resuspend sediments and decrease light availability for SAV (Wright 1995), reducing SAV abundance.

Because SAV are rooted, vascular plants, we can infer that SAV beds adjacent to riprap are negatively affected, at least in part, as a result of changes in sediment stability and composition. Because sediment requirements differ by species (Kemp et al. 2004), we can also infer that some species may be more intensely affected than others. This is important with regard to salinity regime as it relates to SAV community type. There are several more species of SAV found in the tidal fresh and oligohaline zones of the bay and its tributaries than in the mesohaline, and still more than in the polyhaline (Table 1). Therefore, the potential for high diversity in general is greater in the tidal fresh and oligohaline portions of the bay, suggesting that these areas may be, over time, naturally more resilient to disturbance than the mesohaline or polyhaline, which is what Gurbisz et al. (2016) observed in the upper bay following Tropical Storm Lee. SAV beds in the Susquehanna Flats were reduced, but not lost, and recovered steadily in the years following the disturbance. Increased diversity may have assisted this recovery because of the increased likelihood of opportunistic and colonizer species exploiting areas where less tolerant SAV species were reduced from storm impacts. This is also consistent with Patrick et al. (2016), who found greater impacts to SAV adjacent to riprap in polyhaline subestuaries compared to oligohaline subestuaries. The polyhaline region of the bay hosts only two species of SAV and the mesohaline hosts five (Table 1). Comparatively, there are approximately 15 species of SAV commonly observed in the oligohaline and tidal fresh portions of the bay (Table 1), most of which have lower light and less restrictive sediment requirements than either the polyhaline or mesohaline SAV species (Batiuk et al. 2000). Although this study was not designed to assess salinity effects on SAV, we did attempt a post hoc shoreline type by salinity analysis (same methods as shoreline by year analysis described above) of our data. While all salinity regimes were represented, they were unevenly distributed and we found no significant effects, so did not include that analysis here.

\section{Implications Regarding Climate Change and Future Management}

Coastal flooding and submergence of wetlands are projected to increase in the Chesapeake Bay as a result of climate change (Najjar et al. 2010). Compounded by a growing population, hardened shorelines have the potential to rapidly replace the bay's remaining natural shorelines without adaptive regulations. With much of the SAV in the bay characterized as fringing beds that are light-limited to shallow water along those shorelines, this puts the bay's SAV in a precarious position. As the results of this study and others confirm, the rapid expansion of shoreline armoring throughout the bay threatens SAV habitat quality and resilience, and ultimately, its overall abundance. Any reduction in SAV will compromise the ecosystem services that those SAV beds provide (Blake et al. 2014), such as food and refuge for a diversity of commercially, recreationally, and ecologically important organisms, shoreline protection, and carbon sequestration, which is one of our most important tools for mitigating climate change (Fourqurean et al. 2012).

Improving water quality and clarity trends in 2015, however, resulted in increases in SAV throughout Chesapeake Bay, along both natural and armored shorelines. This indicates that some of the stress from armoring could be mitigated by improved water quality and clarity. It should therefore be a priority to maintain and expand efforts such as the Chesapeake Bay TMDL to offset future impacts from population growth and climate change.

Additionally, it will be vitally important to maintain expanses of natural shorelines and forested watersheds throughout the region, and where possible, convert armored shorelines back to their natural state to allow for coastal retreat- 
or the migration of SAV into newly submerged areas as a result of sea level rise. Riprap and other forms of shoreline hardening prevent this inland migration (Saunders et al. 2013).

\section{Conclusion}

SAV is a valuable component of coastal estuaries that is globally threatened by degrading habitat conditions associated with human population pressure. This study demonstrated that shoreline armoring, a pervasive means of preventing shoreline erosion and property loss, acts to degrade SAV habitat quality and resilience at the local scale. Species percent cover, diversity, and evenness were significantly reduced by the presence of riprap revetment. A post hoc analysis also confirmed that SAV is locally affected by watershed land use, although a broad categorization of land use types prevented identification of effects on habitat quality parameters such as species diversity. SAV surveys at long-term monitoring sites showed that SAV recovery, at the local level, took approximately 3 to 4 years following disturbance from large-scale storms and that SAV adjacent to natural shorelines showed more resilience in the years following disturbance. Coinciding increases in bay-wide water quality demonstrated that improved water clarity may hasten SAV recovery and mitigate negative impacts from shoreline armoring, suggesting that progressive and adaptive management of coastal watersheds and their shorelines could offset impacts from anthropogenic stressors and climate change.

Acknowledgements We appreciate the support and assistance of several individuals at the Maryland Department of Natural Resources - particularly Lee Karrh and Mark Lewandowski for their assistance with fieldwork and data collection. We thank the Smithsonian Environmental Research Center and Virginia Institute of Marine Science for the data used in this analysis. Finally, we thank the anonymous reviewers for their comments that greatly improved this manuscript. This work was supported by the National Oceanic and Atmospheric Administration Center for Sponsored Coastal Ocean Research, award number NA09NOS4780220.

Open Access This article is distributed under the terms of the Creative Commons Attribution 4.0 International License (http://creativecommons. org/licences/by/4.0/), which permits use, duplication, adaptation, distribution and reproduction in any medium or format, as long as you give appropriate credit to the original author(s) and the source, provide a link to Creative Commons license and indicate if changes were made.

\section{References}

Batiuk, R.A., R.J. Orth, K.A. Moore, W.C. Dennison, J.C. Stevenson, L.W. Staver, V. Carter, and N.B. Rybicki. 1992. Chesapeake Bay submerged aquatic vegetation habitat requirements and restoration targets: a technical synthesis. US EPA, 68-WO-0043: 186 pp.

Batiuk, R.A., P. Bergstrom, M. Kemp, E. Koch, L. Murray, J.C. Stevenson, R. Bartleson, V. Carter, N.B. Rybicki, J.M. Landwehr,
C. Gallegos, L. Karrh, M. Naylor, D. Wilcox, K.A. Moore, S. Ailstock, and M. Teichberg. 2000. Chesapeake Bay submerged aquatic vegetation water quality and habitat-based requirements and restoration targets: a second technical synthesis. United States Environmental Protection Agency for the Chesapeake Bay Program. $231 \mathrm{pp}$.

Beck, M.W., K.L. Heck Jr., K.W. Able, D.L. Childers, D.B. Eggleston, B.M. Gillanders, B. Halpern, C.G. Hays, K. Hoshino, T.J. Minello, and R.J. Orth. 2001. The identification, conservation, and management of estuarine and marine nurseries for fish and invertebrates. Bioscience 51 (8): 633-641.

Blake, R.E., J.E. Duffy, and J.P. Richardson. 2014. Patterns of seagrass community response to local shoreline development. Estuaries and Coasts 37: 1549-1561.

Brush, G.S., and W.B. Hilgartner. 2000. Paleoecology of submerged macrophytes in the upper Chesapeake Bay. Ecological Monographs 70 (4): 645-667.

Bulleri, F., and M.G. Chapman. 2010. The introduction of coastal infrastructure as a driver of change in marine environments. Journal of Applied Ecology 47: 26-35.

Charlier, R.H., M.C.P. Chaineux, and S. Morcos. 2005. Panorama of the history of coastal protection. Journal of Coastal Research 21 (1): 79-111.

Costanza, R., R. d'Arge, R. De Groot, S. Faber, M. Grasso, B. Hannon, K. Limburg, S. Naeem, R.V. O'neill, J. Paruelo, and R.G. Raskin. 1997. The value of the world's ecosystem services and natural capital. Nature 387: 253-260.

Crooks, S., D. Herr, J. Tamelander, D. Laffoley, and J. Vandever. 2011. Mitigating climate change through restoration and management of coastal wetlands and near-shore marine ecosystems: Challenges and opportunities. Environment Department Paper 121, World Bank, Washington, DC.

Czerny, A.B., and K.H. Dunton. 1995. The effects of in situ light reduction on the growth of two subtropical seagrasses, Thalassia testudinum and Halodule wrightii. Estuaries 18: 418-427.

Duarte, C.M., J. Middleburg, and N. Caraco. 2005. Major role of marine vegetation on the oceanic carbon cycle. Biogeosciences 2: 1-8.

Duarte, C.M., N. Marba, E. Gacia, J.W. Fourqurean, J. Beggins, C. Barron, and E.T. Apostolaki. 2010. Seagrass community metabolism: assessing the carbon sink capacity of seagrass meadows. Global Biogeochemical Cycles 24: GB4032. https://doi.org/10. 1029/2010GB003793.

Duffy, J.T. 2006. Biodiversity and the functioning of seagrass ecosystems. Marine Ecology Progress Series 311: 233-250.

Fourqurean, J.W., C.M. Duarte, H. Kennedy, N. Marbà, M. Holmer, M.A. Mateo, E.T. Apostolaki, G.A. Kendrick, D. Krause-Jensen, K.J. McGlathery, and O. Serrano. 2012. Seagrass ecosystems as a globally significant carbon stock. Nature Geoscience 5 (7): 505-509.

Gittman, R.K., F.J. Fodrie, A.M. Popowich, D.A. Keller, J.F. Bruno, C.A. Currin, C.H. Peterson, and M.F. Piehler. 2015. Engineering away our natural defenses: An analysis of shoreline hardening in the US. Frontiers in Ecology and the Environment. 13 (6): 301-307.

Goforth, R.R., and S.M. Carman. 2005. Nearshore community characteristics related to shoreline properties in the Great Lakes. Journal of Great Lakes Research 31: 113-128.

Griggs, G.B. 2005. The impacts of coastal armoring. Shore and Beach 73 (1): 13-22.

Gurbisz, C., W.M. Kemp, L.P. Sanford, and R.J. Orth. 2016. Mechanisms of storm-related loss and resilience in a large submersed plant bed. Estuaries and Coasts 39 (4): 951-966.

Heck, K.L., Jr., G. Hayes, and R.J. Orth. 2003. Critical evaluation of the nursery role hypothesis for seagrass meadows. Marine Ecology Progress Series 253: 123-136.

Heerhartz, S.M., J.D. Toft, J.R. Cordell, M.N. Dethier, and A.S. Ogston. 2016. Shoreline armoring in an estuary constrains wrack-associated 
invertebrate communities. Estuaries and Coasts 39: 171-188.

Homer, C., J. Dewitz, J. Fry, M. Coan, N. Hossain, C. Larson, N. Herold, A. McKerrow, J.N. VanDriel, and J. Wickham. 2007. Completion of the 2001 National Land Cover Database for the conterminous United States. Photogrammetric Engineering and Remote Sensing 73 (4): 337-341.

Kemp, W.M., R. Batiuk, R. Bartleson, P. Bergstrom, V. Carter, C.L. Gallegos, W. Hunles, L. Karrh, E.W. Koch, J.M. Landwehr, K.A. Moore, L. Murray, M. Naylor, N.B. Rybicki, J.C. Stevenson, and D. Wilcox. 2004. Habitat requirements for submerged aquatic vegetation in Chesapeake Bay: Water quality, light regime, and physicalchemical factors. Estuaries 27 (3): 363-377.

Kemp, W.M., R.W. Boynton, J.E. Adolf, D.F. Boesch, W.C. Boicourt, G. Brush, J.C. Cornwell, T.R. Fisher, P.M. Gilbert, J.D. Hagy, L.W. Harding, E.D. Houde, D.G. Kimmel, W.D. Miller, R.I.E. Newell, M.R. Roman, E.M. Smith, and J.C. Stevenson. 2005. Eutrophication of Chesapeake Bay: Historical trends and ecological interactions. Marine Ecology Progress Series 303: 1-19.

Kenworthy, W.J., and M.S. Fonseca. 1996. Light requirements of seagrasses Halodule wrightii and Syringodium filiforme derived from the relationship between diffuse light attenuation and maximum depth distribution. Estuaries 19: 740-750.

Kenworthy, W.J., J.C. Zieman, and G.W. Thayer. 1982. Evidence for the influence of seagrasses on the benthic nitrogen cycle in a coastal plain estuary near Beaufort, North Carolina (USA). Oecologia 54: 152-158.

Kittinger, J.N., and A.L. Ayers. 2010. Shoreline armoring, risk management, and coastal resilience under rising seas. Coastal Management 38: 634-653.

Koch, E.W. 2001. Beyond light: Physical, geological and geochemical parameters as possible submersed aquatic vegetation habitat requirements. Estuaries 24: 1-17.

Koch, E.W., and G. Gust. 1999. Water flow in tide and wave dominated beds of the seagrass Thalassia testudinum. Marine Ecology Progress Series 184: 63-72.

Kraus, N.C., and O.H. Pilkey. 1988. The effects of seawalls on the beach: an extended literature review. Journal of Coastal Research SI 4: 1-28.

Laffoley, D., and G. Grimsditch (eds). 2009. The management of natural coastal carbon sinks, 53. Gland: IUCN.

Li, X., D.E. Weller, C.L. Gallegos, T.E. Jordan, and H. Kim. 2007. Effects of watershed and estuarine characteristics on the abundance of submerged aquatic vegetation in Chesapeake Bay subestuaries. Estuaries and Coasts 30 (5): 840-854.

Living Shoreline Steering Committee. 2006. Proceedings of the 2006 Living Shoreline Summit, Chesapeake Bay, CRC Publ. No. 08-164.

Livingston, R.J., S.E. McGlynn, and X. Niu. 1998. Factors controlling seagrass growth in a gulf coastal system: Water and sediment quality and light. Aquatic Botany 60 (2): 135-159.

Lotze, H.K., H.S. Lenihan, B.J. Bourque, R.H. Bradbury, R.G. Cooke, M.C. Kay, S.M. Kidwell, M.X. Kirby, C.H. Peterson, and J.B.C. Jackson. 2006. Depletion, degradation, and recovery potential of estuaries and coastal seas. Science 312 (5781): 1806-1809.

McGlathery, K.J., K. Sundback, and I.C. Anderson. 2007. Eutrophication in shallow coastal bays and lagoons: The role of plants in the coastal filter. Marine Ecology Progress Series 348: 1-18.

Mcleod, E., G.L. Chmura, S. Bouillon, R. Salm, M. BBjork, C.M. Duarte, C.E. Lovelock, W.H. Schlesinger, and B.R. Silliman. 2011. A blueprint for blue carbon: Toward an improved understanding of the role of vegetated coastal habitats in sequestering $\mathrm{CO}_{2}$. Frontiers in Ecology and the Environment 9 (10): 552-560.

Moore, K., D. Wilcox, and R. Orth. 2000. Analysis of the abundance of submersed aquatic vegetation communities in the Chesapeake Bay. Estuaries 23 (1): 115-127.

Morley, S.A., J.D. Toft, and K.M. Hanson. 2012. Ecological effects of shoreline armoring on intertidal habitats of a Puget Sound urban estuary. Estuaries and Coasts 35: 774-784.

Najjar, R.G., C.P. Pyke, M.B. Adams, D. Breitburg, C. Hershner, M.
Kemp, R. Howarth, M.R. Mulholland, M. Paolisso, D. Secor, K. Sellner, D. Wardrop, and R. Wood. 2010. Potential climate-change impacts on the Chesapeake Bay. Estuarine, Coastal, and Shelf Science 86: 1-20.

National Research Council (NRC). 2007. Mitigating shore erosion along sheltered coasts, $188 \mathrm{p}$. Washington: The National Academies Press.

O'Connor, M.C., J.A.G. Cooper, J. McKenna, and D.W.T. Jackson. 2010. Shoreline management in a policy vacuum: A local authority perspective. Ocean \& Coastal Management 53: 769-778.

Orth, R.J., and K.A. Moore. 1984. Distribution and abundance of submerged aquatic vegetation in Chesapeake Bay: An historical perspective. Estuaries 7 (4): 531-540.

Orth, R.J., T.J.B. Carruthers, W.C. Dennison, C.M. Duarte, J.W. Fourqurean, K.L. Heck Jr., A.R. Hughes, G.A. Kendrick, W.J. Kenworthy, S. Olyarnik, F.T. Short, M. Waycott, and S.L. Williams. 2006. A global crisis for seagrass ecosystems. Bioscience 56 (12): 987-996.

Orth, R.J., M.R. Williams, S.R. Marion, D.J. Wilcox, T.J.B. Carruthers, K.A. Moore, W.M. Kemp, W.C. Dennison, N. Rybicki, P. Bergstrom, and R.A. Batiuk. 2010. Long-term trends in submersed aquatic vegetation (SAV) in Chesapeake Bay, USA, related to water quality. Estuaries and Coasts 33: 1144-1163.

Patrick, C.J., D.E. Weller, X. Li, and M. Ryder. 2014. Effects of shoreline alteration and other stressors on submerged aquatic vegetation in subestuaries of Chesapeake Bay and the Mid-Atlantic coastal bays. Estuaries and Coasts 37: 1516-1531.

Patrick, C.J., D.E. Weller, and M. Ryder. 2016. The relationship between shoreline armoring and adjacent submerged aquatic vegetation in Chesapeake Bay and nearby Atlantic coastal bays. Estuaries and Coasts 39: 158-170.

Perry, M.C., R.E. Munro, and G.M. Haramis. 1981. Twenty-five year trends in diving duck populations in Chesapeake Bay. Transactions of the North American Wildlife and Natural Resources Conference 46: 299-310.

Perry, M.C., A.M. Wells, D.M. Kidwell, and P.C. Osenton. 2007. Temporal changes of populations and trophic relationships of wintering diving ducks in Chesapeake Bay. Waterbirds 30: 4-16.

Saunders, M.I., J. Leon, S.R. Phinn, D.P. Callaghan, K.R. O’Brien, C.M. Roelfsema, C.E. Lovelock, M.B. Lyons, and P.J. Mumby. 2013. Coastal retreat and improved water quality mitigate losses of seagrass from sea level rise. Global Change Biology 19 (8): 2569-2583.

Scyphers, S.B., J.S. Picou, and S.P. Powers. 2015. Participatory conservation of coastal habitats: The importance of understanding homeowner decision making to mitigate cascading shoreline degradation. Conservation Letters, A Journal of the Society for Conservation Biology 8 (1): 41-49.

Stancheva, M., N. Rangel-Buitrago, G. Anfuso, A. Palazov, H. Stanchev, and I. Correa. 2011. Expanding level of coastal armouring: Case studies from different countries. Journal of Coastal Research SI 64: $1815-1819$.

Straub, J.N., R.J. Gates, R.D. Schultheis, T. Yerkes, J.M. Coluccy, and J.D. Stafford. 2012. Wetland food resources for spring-migrating ducks in the Upper Mississippi River and Great Lakes region. The Journal of Wildlife Management 76: 768-777.

Waycott, M., C.M. Duarte, T.J.B. Carruthers, R.J. Orth, W.C. Dennison, S. Olyarnike, A. Calladinea, J.W. Fourqurean, K.L. Heck Jr., A.R. Hughes, G.A. Kendrick, W.J. Kenworthy, F.T. Short, and S.L. Williams. 2009. Accelerating loss of seagrass across the globe threatens coastal ecosystems. PNAS 106 (30): 12377-12381.

Wright, L.D. 1995. Morphodynamics of inner continental shelves. Boca Raton: CRC

Wyda, J.C., L.A. Deegan, J.E. Hughes, and M.J. Weaver. 2002. The response of fishes to submerged aquatic vegetation complexity in two ecoregions of the Mid-Atlantic Bight: Buzzards Bay and Chesapeake Bay. Estuaries 25 (1): 86-100. 